\title{
Is the Staged Vagina Always White?
}

\author{
Midori Takagi \\ Fairhaven College, Western Washington University, \\ 516 High Street, Bellingham, WA 98225-9118
}

\begin{abstract}
In 2003 the Women's Center, a student-led organization, at Western Washington University opened a new show called The Vagina Memoirs. This new program replaced the annual V Day production of Eve Ensler's 1996 play The Vagina Monologues (TVM) with the argument that Ensler's approach was "racist and transphobic" (Kato, H. 2013, personal communication, June). This piece, however, is not to debate the Vagina Monologues, but to use it as a starting point to discuss the problems with producing documentary plays that focus on the self and the "free" ability or "choice" that artists have in presenting "truths" about themselves especially when the group is constituted by racial and sexual minorities. People of color and sexual minorities have not and are not afforded the same freedoms to voice their experiences because of historical and structural factors that limit who gets to speak, what they are "permitted" to say, and whether their messages are actually understood and heard. As I argue below, while the presentation of diverse voices within documentary plays suggests a level of egalitarianism, equity and choice, this façade masks how relations of power affect the gathering, writing, and the public production of minority lived experiences. I discuss these problems within the context of the experiences that have occurred on my campus and the students' creation of their own documentary play called the Vagina Memoirs.
\end{abstract}

Keywords: The Vagina Monologues

DOI: $10.7176 / \mathrm{JEP} / 10-21-13$

Publication date:July $31^{\text {st }} 2019$

\section{Introduction}

The last time I saw the Vagina Memoirs, (Memoirs), in 2014, the annual college performance ended with nine individuals holding hands and bowing to hundreds of audience members who stood in ovation. This cast was smaller than usual — on average there are 15 participants - nonetheless, the significance of the night was hardly diminished; the cast had bravely given their testimonials, which over several nights meant that over 1500 viewers including family, friends, lovers, professors, and university staff members had heard their narratives of joy, pain, hilarity, anguish, and optimism.

Like many in the audience, I was not surprised by the premise of the production; the program bore similarity to Eve Ensler's The Vagina Monologues (TVM), a vastly popular play performed yearly on hundreds of college campuses that focuses on "vagina" tales (stories of sexual experience interspersed with vagina "facts"). Fewer, however, recognized the important distinctions between TVM and the Memoirs, as the latter purposely stepped away from predominantly "feel good" vagina politics to focusing on the body as a contested ground between oppression and liberation.

At the close of the show, the cast was elated and proud of their accomplishments; I have yet to meet a participant who regrets giving their memoir. Everyone is glad that they spoke their "truth" to their friends, family and the larger university community. The enthusiasm shown by the audience (and their responses to the questionnaires distributed at each show), support the claim that the Memoirs was the most popular production on campus.

Yet in spite of its popularity and its professed aim as a "feminist" practice, the program has had some difficulty being fully inclusive and sensitive to the differences based on race, gender, and sexuality even with its frequent representation of diverse individuals. In fact, in 2013, one performer devoted their onstage monologue detailing how the Memoirs was more damaging to them than helpful because of the racism that pervaded the preproduction process. This article argues that campus feminist productions, such as this one, where first-person narratives are offered as evidence of personal and social injustices need oversight and some critique by staff, cast, and faculty to ensure that the goals of educating students (performers and audience) does so in a manner that does not encourage forms of self-interested individualism and replicate whiteness.

\section{Definitions}

In this article, I define self-interested individualism as a more extreme form of individualism as laid out by Tocqueville, psychologists and educators. Tocqueville used individualism to connote self-reliance and separation as distinct American attributes (Tocqueville 1838, 2000). Triandis builds on this notion to include being "autonomous and independent from their in-groups...[to] give priority to their personal goals over the goals of their in-group...[to] behave primarily on the basis of their attitudes rather than the norms of their in-groups..." (909). Influenced by Cavieres-Fernandez, I refer to self-interested individualism as a form that stresses the self 
and achieving their interests with limited regards to public and group concerns. Furthermore, I contend that this form of individualism, as structured through the Memoirs process, is based on a notion of egalitarianism that presupposes that all individuals participating in the production have equal access and ability to achieve their specified goals.

In terms of whiteness, I defer to Frankenberg who defines it as "a location of structural advantage in societies structured in racial dominance," as well as a "site of elaboration or a range of cultural practices and identities, often unmarked and unnamed..." (76). Commonly, whiteness is the norm and yet through its normativity it is invisible to its holders and masks the ways that white people derive advantages, "protection and benefits..." (Shome 366).

\section{Background of Memoirs}

The Memoirs was originally envisioned as a response to TVM. In the early 2000s, the university had staged a few performances of Ensler's play, but quickly student staff at the campus Women's Center (WC) found the show to be "problematic." One student staff member, Jessica Sele, noted that "the monologues written specifically for women of color are victimizing, leaving the white women in the play to do the more empowering ones" ("Women's Center Not to Produce"). Hana Kato, another student staffer, also found the production to be racist, but transphobic as well because of its sole focus on a/the vagina as defining a woman.

The problems with TVM prompted WC to consider other options, including a new and different vision for a woman-based production altogether. According to one staffer, "We wanted [to have a] "community project based around issues [concerning] people in the community and have that be about experience around gender and body focused usually" (Sele, J. 2013, personal communication, May). This resonated with students because there was a strong desire among them to explore and relay their own stories and to create something that was "more truthful" about themselves (Kato, H. 2013, personal communication, June).

In the academic year 2003-4, the WC introduced a new stage production entitled: Vagina Memoirs (Memoirs). This play featured college women performing pieces written by them and about themselves. The Memoirs paid homage to TVM, in the sense that it was "a safe place to talk about your experiences with other vagina havers," maintained the word vagina in its title, and was not a play in the traditional sense: no scenery, no props, or costumes (Kato, H.2013, personal communication, June).

A few years after the Memoirs had been launched, the WC staff came to realize that the program could be charged with the same criticisms they held about TVM. The overwhelming majority of performers were white cisgender straight women and it appeared that many students on campus associated the Memoirs with that group alone. To combat the perception, and at times the reality, that the Memoirs was dominated by heterosexual whites, the WC staff reached out to various racial, sexual, and gender minority student clubs to increase cast diversity. Throughout a decade, some years they were more successful than others; racial minorities have constituted as little as $20 \%$ and as much as $50 \%$ of the cast on a campus that is $72 \%$ white.

In addition, the staff found focusing on the vagina was limiting and essentializing and in 2006, they invited anyone who was not cisgender male to join the show. As one of the staff members responsible for pushing some of these changes explains, "I remember feeling like I wanted to bring some personal change to the process, so I was like I just don't want to see this be a production just for white women anymore, I really want to see this be a production that has like multiple identities represented that is trans and gender queer inclusive...." (Majkut, D. 2013, personal communication, July). Except in the production's name (which does create confusion), the Memoirs no longer emphasized the vagina and invited anyone who considered themselves to be a woman or is femalebodied, and/or who holds a marginalized gender identity. Over the years, an increasing number of transgender and genderqueer individuals did join the production and discussed their identity in their narratives. In 2010, the first transgender cast member presented their memoir and three years later at least three genderfluid individuals were featured in the show.

The staffers took great pains to educate themselves and cast members about diversity, power, and privilege. Most staffers, for example, understood that diversity was more complex than a cast of women-identified individuals who look different from one another or live under different circumstances. In fact, over a ten-year period there had been a growing awareness, particularly among the members of WC, of the theory of intersectionality. Staffers understood that individuals, particularly women of color, experience racism and sexism simultaneously, which white women do not (Mann 54). Furthermore, they understood these interlocking oppressions are part of a structure of power and subordination that have shaped women of color's experiences and their perspectives (Crenshaw). Admittedly, the depth of knowledge about intersectionality varied from staffer to staffer, but all recognized these critical issues and how they affect building communication, trust and group bonding among cast members. One former cast member-turn-staff understood this lesson well: "when I was a part of the process [as a cast member] there wasn't enough conversation about power dynamics in the cast...there wasn't a lot of communication between white women in the cast and women of color... and I thought that...people needed to be talking about power dynamics and as it relates to truth telling and storytelling especially" (Kloub, A. 
2013, personal communication, June).

To help the cast talk "about power dynamics," the staff introduced articles and handouts, films, and conducted exercises and workshops concerning power, privilege and oppression. Though the term consciousness-raising was never mentioned, these workshops function on the same premises as it's feminist origins. One year the facilitators led members through a hypnosis activity borrowed from Augusto Boal, the founder of the "Theatre of the Oppressed." The "Columbian Hypnosis" is basically the game "Follow the Leader," in that the hypnotist controls the movements of the hypnotized, but it actually goes much deeper. As Souto-Manning, a professor of teacher education explains, it "plays with physical, social, and political awareness of self and others and explores issues of positionality and point of view...." (999). These same staff members also assigned materials written by Peggy McIntosh and Audre Lorde to prompt discussion and journaling on issues of "unearned advantages," power, and silence (Kloub, A. 2013 personal communication, June). Two years in a row, I along with a student leader, held a workshop that explained the history of social stratification in the United States and how every participant possesses unearned invisible privileges in addition to disadvantages because of that hierarchical system. To underscore this point, the student co-teacher had the cast play "Cross the Room (Line)"; a series of statements are spoken aloud such as "Anyone who has experienced the effects of alcoholism in their family," or "Anyone who has a family member who is gay, lesbian, bisexual or transgender" and if a participant has experienced any of the statements, they move across the room. By seeing how often fellow cast members cross the room, each participant becomes aware that no one has a monopoly on privilege or oppression (Cohen, E. 2013 personal communication, May; Brandson, C. 2013, personal communication, May). The point of these exercises, wrote a staffer, "[is] to help the cast understand the ways in which each of their stories are shaped by the larger systems in which we interact as gendered and racialized people" (Kloub, A. 2013, personal communication, June).

\section{The Problem}

In 2013, several cast members charged the Memoirs process, and fellow cast and staff members, with racial insensitivity. I was asked by the students, because I am their faculty advisor, to investigate these charges. As part of my agreement, I asked three student volunteers - all of whom were either currently or had been a part of the Memoirs--to help gather research and data. We conducted extensive phone, in-person and e-mail interviews with the coordinators of the production dating back to 2003 and as many present and former performers within the past 10 years. A closer examination of the pre-production process surfaced ways that the staging of the Vagina contained and sublimated differences and inhibited any real engagement with the structural effects of racism through its staffing and ultimately its focus on the "self" and notions of egalitarianism.

\section{Staffing}

For nearly a decade, the coordinators of the Women's Center, which sponsored the production, have been mostly white women and majority cisgender females. The staff of the Memoirs have also been mostly white cisgender females. This phenomenon has been identified by many of the WC's coordinators, the Memoirs' facilitators and cast members themselves, as being problematic and they have tried to diversify. Yet a pattern had been largely set, as one former facilitator explained, '[the Memoirs] has a history of being a production for cis white women...who does it get passed down to? Cis white women, again. And what stores are being told? Cis white women again. And who picks the facilitator? The cis white women who facilitated the year before...." (Majkut, D. 2013, personal communication, July). The pattern of having white mostly cisgender females as staffers created an informal system of nepotism; friends of the staffers would be encouraged to apply and commonly they too were white cisgender females. On the surface, this process may seem logical to the staff because open job positions at the WC are frequently advertised by word-of-mouth in addition to formal recruitment postings. This informal system of advertising, however, reproduces whiteness by hiding the racial pattern of friendship ties that give advantages to the dominant group (Royster qtd. in Boulton 392) and narrows the entry of non-white, noncisgendered individuals. This process also solidifies a racialized distribution of opportunities and material power-what George Lipsitz calls "the possessive investment in whiteness" (372).

\section{Check-ins}

Weekly, and sometimes bi-weekly, the staff and cast would meet do perform a "check-in." These were the occasions when everyone would speak about the "self." Members shared their personal experiences and learned more about one another in a "nonjudgmental" way - meaning they could tell their stories without fear of being shamed, doubted, or criticized (Cohen, E. 2013 personal communication, May; Brandson, C. 2013, personal communication, May). This is the place where participants broached "sensitive topics" that society generally considers too intimate for the public such as the act of sex, sexual violence, physical child or adult-hood abuse, and eating disorders (Hyden 223). Many members found these opportunities to be cathartic and therapeutic. A majority of the casts interviewed found these meetings liberating because it is where you: "get stuff off [your] chest," "talk about hard issues," voice things that are never spoken at the "dinner table" or even with "people that 
you're close with"; and "[break] the silence" (Rodriguez, C. 2015 personal communication May; Pelham, B. 2015 personal communication, May; Lohr, C. 2015, personal communication, May). By sharing their experiences and being listened to, members had a greater likelihood to recognize some of the processes through which they were stigmatized and begin to question their assumptions, and consciously reject negative labels. Psychologists and social workers indicate that these important steps can lead to greater self-awareness, which "allows them to learn from others, plan alternative strategies, regulate individual behavior, and engage in self-reflection." Furthermore, this can lead to individuals with the "capability of altering their environment and influencing their action" (Becker et al. 328; Christens; Gutierrez).

The structured emphasis on the self does not mean that other members were not affected. During these sharing sessions, other levels of awareness occurred. For some members, it was the expansion of their worldviews. At first glance, this response might seem strange given how many Americans and the media describe the United States as being culturally, ethnically and socially diverse; one would think we all live in multi-cultural neighborhoods. Conditions such as persistent economic poverty in urban areas and racial residential segregation, however, have isolated and insulated communities from cross-cultural, inter and intra-cultural relations (Williams and Collins; Massey and Denton). In addition, there have been more and more fervent calls for the assimilation of "others" rather than supporting pluralism in response to the attacks on 9/11 (Jackson). As a result, it is not uncommon for college students to encounter classmates of different racial, religious, and economic communities for the first time. One woman, for example, who was raised in a deeply religious Muslim community found the experience, "eye opening": "[J]ust hearing people's perspectives, people's stories, whether it was a transgender identity or them experiencing homophobia...things like that, I haven't personally experienced" (Dawud, H. 2013, personal communication, May).

There were, however, some difficulties with the rules of discussion that inhibited any deepening of understanding across racial and sexual boundaries and to the ways that oppression works. This format of discussion - the rules of discourse - in essence limited what could and could not be said. As Stuart Hall explains,

[Discourse] governs the way that a topic can be meaningfully talked about and reasoned about. It also influences how ideas are put into practice and used to regulate the conduct of others. Just as a discourse 'rules in' certain ways of talking about a topic, defining an acceptable and intelligible way to talk, write or conduct oneself, so also, by definition, it 'rules' out' limits and restricts other ways of talking, of conducting ourselves in relation to the topic or constructing knowledge about it. (qtd.in Macalpine and Marsh 432).

The discourse of focusing on the "self" ironically had the effect of silencing some members as they compared and contrasted their experiences. Students of color from the 2013 cast, for example, believed that telling about incidents of racism palled in comparison to someone's experiences of sexual assault. As one cast member of color explained, "it seems insensitive to talk about an incident of racism after hearing that someone was raped" (Dawud, H. 2013 personal communication, May). While this type of silencing was self-imposed it does surface some of the ways that certain forms of oppression are privileged over others and may add to the sense of powerlessness for non-white participants. The lack of discussion, in this case, legitimized hegemonic whiteness while highlighting hegemonic masculinity.

Staff assumed that cast members desired to speak about themselves and that the space rules created an egalitarian environment without recognizing "the reality of social injustices that are bound to permeate the group experience" (Burnes and Ross 171). Traditionally, in feminist spaces that are dominated by whites, disclosing personal experiences has been "central, expected and rewarded" (Srivastava qtd. in Bunjun 119). Historically, the voices of subordinated minorities have not been welcomed, embraced or heeded in those same environments. The "check-ins" then were structured and carried out on the basis that "assumes equal speaking positions and that all women involved would be hearing and speaking on the same terms." And, as Bunjun argues, "when assuming equal space for sharing, relations of power are not acknowledged..." (119). Staffers were not alone in this oversight; during interviews with white cast members I shared this information about self-silencing and received mixed responses, as one participant pointed out, "that's a shame, but it was their choice" (Anonymous, b. 2013, personal communication, May). This statement re-emphasizes how notions of egalitarianism were presupposed in the making of this documentary play.

Another weakness of this discourse is that the stories were being told as abstracted narratives with no way to make it intelligible on a broader context, which has several stultifying outcomes. White cisgendered participants were able to make claims for their own marginalization, but were not held accountable to fully understanding other subordinated experiences. At the same time, non-white and non-binary gender members felt constrained from revealing certain stories about themselves without contextual information because they believed it would reify unfounded ideas held by the dominant group. One participant, for example, did not want to talk about their strained relationship with their father because it would simply conjure up "stereotyped notions about Black men and violence" (Canton, C. 2013, personal communication, June).

Fellows and Razack believe this weakness is more damaging than simply de-contextualizing experiences. 
The dominant group, by virtue of their privileged positions, end up viewing others' narratives through "the lenses of [their] own superiority and utilize dominant explanatory frameworks to explain to [themselves] the meaning of [the others'] lives" (335). In other words, not only do minority members not get to explain the larger frameworks, but those contexts are simply imagined through the dominant lens. And the dominant lens rarely explains how the most privileged are "implicated in the subordination of" others (Fellows and Razack 340).

Sadly, the discourse of the "self" is also where the greatest possibilities for racial microaggressions could and did occur. Racial microaggressions, according to psychologist Sue, are described as "brief and commonplace daily verbal, behavioral, and environmental indignities, whether intentional or unintentional, that communicate hostile, derogatory, or negative racial slights and insults to the target person or group" (Sue et al. 273). Frequently, cast members of the dominant group highlighted the injustices they face as women in the classroom, on campus or in their part-time jobs without acknowledging how their race privileges them. As one cast of color quipped, "they just focused on gender stuff, but they didn't think about the other stuff...it was a tokenizing issue" (Canton, C. 2013 personal communication, June). On another occasion, after watching a film about an African woman in Oakland, CA., who experiences having her name consistently mispronounced, a number of white cast members excitedly responded "Yeah! That is exactly how I experience my name!" leaving a Black member wondering what message they actually received from the video. Further compounding the situation, on a different day, a white cast member described her upcoming service learning trip to Central America as "going to Mexico, but not the nice Mexico" (Anonymous. a. 2013, personal communication, May).

The staff member in charge did speak to several offending cast members, but it is not clear to the extent that the participant understood or cared. As one white cast member pointed out "if I wanted to learn about that stuff [racial microaggressions and racism] I would have taken a class, but this isn't a class" (Anonymous, b. 2013, personal communication, May).

There is an overwhelming impulse to attribute these microaggressions to specific individuals and simply hold them accountable. But to do so overlooks how the process and social structure of the Memoirs production allows for systematic racism and the pervasiveness of whiteness under the guise of the "self" and egalitarianism.

\section{Staging the Vagina}

The on-stage production is where the saying "the personal is political" is showcased and celebrated. The importance of "telling one's truth" cannot be understated. There is plenty of precedence for using theatre and personal narratives as a way to empower individuals. Social psychologists, sociologists, social work, social justice and theatre educators have long detailed the success of using the arts based on personal narratives as instruments for social change in local communities (Sonn et al. 244). The "personal is political," in this feminist context, however, does not necessarily lead to politicizing issues and raising meaningful awareness.

The format of presenting "one's truth," though visually and aurally powerful, tends to present the voices of non-white, non-binary gender members in a way that makes them visible while simultaneously rendering them invisible. Their skin-color and gender-identity marks them as being "different" (in comparison to unmarked whiteness and being a part of the dominant binary gender construct) and so their stories are viewed through the dominant lens of being exotic and unusual. In contrast, "normal" unmarked white stories appear to demand serious contemplation from the audience because they're about "regular" people. In fact, when asked about their race, white performers interviewed acknowledged they possessed light-skin color and some identified that they received benefits from being white. But when asked whether they identified their race as part of their monologue, a majority of the cast replied that race did not have to do with the personal narrative and that if race did they would have said something about it. In contrast, nearly all of the non-white performers interviewed did acknowledge that race played a role in their narrative and they spoke about it onstage during their monologue.

In addition, because there is a lack of contextual information, the conditions that racial and sexual minorities speak of are assumed to be culturally or family-related ones, whereas the "normal" stories are seen as narratives of oppression because of the larger forces of patriarchy and anti-progressive sexual morals (Shome 368). An example of this occurred when a white cisgender woman discussed her right to dress as a "slut" and demanded the freedom to choose how she presents her sexuality. Later in the same show, a dark-skinned Muslim woman spoke about her life as a veiled individual. Audience members during the former presentation shouted out "Fuck Men!" and "Fuck Patriarchy!" but were relatively silent during the latter monologue. Though I am not certain what the audience was thinking, I do believe they were unsure who or what to say "Fuck" to: her family? her religion? how about to Americans' racist treatment of Muslim people?

The staging of the monologues - one right after another--also served to flatten the experiences. Each expression becomes a single-serving or "one flavor amid a smorgasbord of difference," as Mane describes (81). This is problematic because it presents a view that everyone and their subordinated experiences are equal and that the cast speaks with the same amount of openness and position of strength. This type of staging encourages notions of individualism and egalitarianism that masks the structural inequalities that oppress non-white and non-binary gender folks that do not affect their dominant white counterparts. As Lykke and Braidotti state, "We all have 
bodies, but not all bodies are equal, some matter more than others; some are, quite frankly, disposable" (136). Historically and traditionally, people of color and non-binary gender folks have been discriminated against by law, in schools, in the workplace, and on the street. This long legacy of prejudice and violence, however, does not get full recognition when a person's experience is sandwiched in between experiences of the "norm." Granted, the "norm" are also stories of pain and loss, but there is, what Michelle Fine explains, a "kind of "flattening' of intersectionality, with racial disparities in health, education or criminal justice appearing to be artifacts of culture or genetics, rather than systemic effects of cumulative oppression" (Berger and Guidroz 69).

Last, but not least, the "smorgasbord" approach, particularly in the large school event hall, encourages and creates entertainment or "infotainment." The thousands of family, friends, and students who come and view the Memoirs annually have expectations of being shocked, thrilled, saddened, and rejoiced by the monologues. For a short time the University sponsored an online discussion board (Viking Village) where any student could write about events on campus or anything to do with campus life. Following the 2013 production, a few postings appeared that inappropriately addressed a minority cast member in sexually objectified ways. This raises grave doubts as to the political message and awareness received by the audience. In addition, during the intermission, audience members, overheard by the cast, frequently critiqued the monologues as to whether they were powerful or funny.

For racial and sexual minority cast members, this form of infotainment can be most damaging. As Srivastava and Francis explain, "In particular, the demand for 'authentic experience' from people of color can reproduce voyeurism of the multicultural exchanges in which display of culture, song and dance is a stand-in for meaningful changes in our relationships with each other" (282).

\section{Conclusion}

In spite of the possibilities and potentials, the staging of these narratives does not lead to making those "structures of domination" visible. Instead, the structure of the Memoirs show acts to abstract and decontextualize the experiences of the performers so that historical patterns of oppression and discrimination are masked. Worst, because those patterns have masked the narratives, particularly those by students of color, their issues and concerns become flattened and are "submerged within a host of more trivial differences" (Hill Collins qtd. in Mane 81). Intersectionality, then becomes what Sirma Bilge calls "ornamental intersectionality," where difference and diversity serves to punctuate the exotic and allows for the reproduction and pervasiveness of the normativity of whiteness (408).

I am not immune to how powerful personal narratives are and can be in the documentary feminist project. Cast members do emphasize how empowering it is to speak their "truths" to thousands. Yet that empowerment is achieved on very individualistic terms and does so by oppressing other subordinate voices (Shugart et al. 195). And there is little evidence that, after ten years, the Memoirs has launched an activist movement, or even deepened students' awareness of structural inequalities and the oppression of people of color and non-binary gendered folks. As a result, I am left wondering whether this production should continue and at what cost? Must the staged vagina always be white?

\section{Addendum}

In the spring of 2013, I wrote my findings in a report to the university with my recommendations that the production needed to be overseen by more than the WC and required a reconceptualization of its structure. This was not a popular report and I even received an angry and insulting message from a former Memoirs staff member to "mind my own business" and "stop butting into areas that are not of my concern." To some degree that person is correct; I am not a staff member. I am, however, a concerned faculty member who has put student welfare, and particularly students of color wellbeing, at the forefront of my work. Looking at the Memoirs process has been instructive to me and the students who helped with this project, in considering how diversity and feminism is "managed" on campus and even within my classroom. For the last three years, the Vagina Memoirs has not been produced, but not because of my report. Spearheaded by a group of students of color, a new visual-arts based show called Memoirs, has replaced it. This show features art installations, mixed media and other forms of more traditional portraits, along with accompanying explanations, that reflect the ways that each member has come to embody their identities and the structural forces that affect them.

\section{Notes}

1. This first production was actually named Vagina Dialogues, but the title soon changed to Vagina Memoirs.

\section{References}

Becker, Julie Kovach, Andrea Crivelli, and Dickie Lynn Gronseth. (2004), "Individual Empowerment: How Community Health Workers Operationalize Self-Determination, Self-Sufficiency, and Decision-Making 
Abilities of Low-Income Mothers", Journal of Community Psychology 32(3), 327-42.

Berger, Michele Tracy and Kathleen Guidroz. (2009), "A Conversation with Founding Scholars of Intersectionality: Kimberle Crenshaw, Nira Yuval-Davis and Michelle Fine", in Berger, Michele Tracy and Kathleen Guidroz (eds.) Intersectional Approach: Transforming the Academy through Race, Class, and Gender. Chapel Hill: The University of North Carolina Press, 61-80.

Bilge, Sirma. (2013), "Intersectionality Undone: Saving Intersectionality from Feminist Intersectionality Studies", DuBois Review: Social Science Research on Race 10(2), 405-424.

Boulton, Christopher. (2015), "Under the Cloak of Whiteness: A Circuit of Culture Analysis of Opportunity Hoarding and Colour-Blind Racism Inside US Advertising Internship Programs", Triple C 13(2), 390-403.

Bunjun, Benita. (2010), "Feminist Organizations and Intersectionality: Contesting Hegemonic Feminism", Atlantis 34(2), 115-26.

Burnes, Theodore R., and Katherine I Ross. (2010), “Applying Social Justice to Oppression and Marginalization in Group Process: Interventions and Strategies for Group Counselors", The Journal for Specialists in Group Work 35(2), 169-76.

Cavieres-Fernandez, Eduardo. (2014), “Teachers' Experiences and Teaching Civic Engagement Beyond SelfRegarding Individualism", Teaching and Teacher Education 42, 1-10.

Christens, Brian D. (2012), "Toward Relational Empowerment”, American Journal of Community Psychology 50 , 114-28.

Crenshaw, Kimberle. (1994), "Mapping the Margins: Intersectionality, Identity Politics, and the Violence Against Women of Color" in Fineman, Martha Albertson and Roxanne Mykitiuk (eds.) The Public Nature of Private Violence. New York: Routledge, 93-118.

Ensler, Eve. (2001), The Vagina Monologues, London: Virago Press Ltd.

Fellows, Mary Louise, and Razack, Sherene. (1997), "The Race to Innocence: Confronting Hierarchical Relations Among Women." The Journal of Gender, Race \& Justice 1, 335-52.

Frankenberg, Ruth. (2001), "The Mirage of an Unmarked Whiteness" in Rasmussen, Birgit Brander, Eric Klinenberg, Irene J. Nexica and Matt Wray (eds.) The Making and Unmaking of Whiteness. Durham: Duke University Press, 72-96.

Gutierrez, Lorraine M. (1990), "Working with Women of Color; An Empowerment Perspective.” Social Work 35 , 149-54.

Hyden. Margareta. (2008), "Narrating Sensitive Topics" in Andrews, Molly, Corinne Squire and Maria Tamboukou (eds.) Doing Narrative Research. London: Sage Publications Ltd., 223-239.

Jackson, Liz. (2010), "The New Assimilationism: The Push for Patriotic Education in the United States Since September 11", Journal of Critical Education Policy Studies 8(1), 108-136.

Lipsitz, George. (1995), "The Possessive Investment in Whiteness: Racialized Social Democracy and the 'White' Problem in American Studies", American Quarterly 47(3), 369-87.

Lykke, Nina, and Braidotti. (1996), Between Monsters, Goddesses, and Cyborgs: Feminist Confrontations with Science, Medicine, and Cyberspace. NJ: Zed Books.

Macalpine, Marion, and Sheila Marsh. (2005), “On Being White: There's Nothing I Can Say”, Management Learning 36(4), 429-50.

Mane, Rebecca L. Clark. (2012), "Transmuting Grammars of Whiteness in Third-Wave Feminism: Interrogating Postrace Histories, Postmodern Abstraction, and the Proliferation of Difference in Third-Wave Texts", Signs 38(1), 71-98.

Mann, Susan Archer. (2013), “Third Wave Feminism's Unhappy Marriage of Poststructuralism and Intersectionality Theory", Journal of Feminist Scholarship 4, 54-73.

Massey, Douglas S. and Nancy A. Denton. (1993), American Apartheid: Segregation and the Making of the Underclass. MA: Harvard University Press.

Shugart, Helene A., Waggoner, Catherine Egley, and Hallstein, D. Lynn O’Brien. (2001), "Mediating Third-Wave Feminism: Appropriation as Postmodern Media Practice”, Critical Studies in Media Communication 18(2), 194-210.

Shome, Raka. (2000), “Outing Whiteness”, Critical Studies in Media Communication 17(3), 366-71.

Sonn, Christopher C., Quayle, Amy F., Belanji, Belinda, and Baker, Alison M. (2015), "Responding to Racialization Through Arts Practice: The Case of Participatory Theater", Journal of Community Psychology 43(2), 244-59.

Souto-Manning, Mariana. (2001), "Playing with power and privilege: Theatre games in teacher education", Teaching and Teacher Education 27, 997-1007.

Srivastava, Sarita and Margot Francis. (2006), "The Problem of 'Authentic Experience': Storytelling in Antiracist and Anti-Homophobic Education”, Critical Sociology 32(2), 275-307.

Sue, Derald Wing, Capodilupl, Christina, Torino, Gina C., Bucceri, Jennifer M., Holder, Aisha, Nadal, Kevin L., and Esquilin, Marta. (2007), "Racial Microaggressions in Everyday Life: Implications for Clinical Practice", 
American Psychologist 62(4), 271-86.

Tocqueville, Alexis de. (1838, 2000), Democracy in America, trans. H. Mansfield and D. Winthrop. Chicago: University of Chicago Press.

Triandis, Harry C. (2001), "Individualism-Collectivism and Personality", Journal of Personality 69(6), 907-24.

Williams, David R. and Chiquita Collins. (2001), "Racial residential segregation: a fundamental cause of racial disparities in health", Public Health Reports 116(5), 404-416.

“Women's Center Not to Produce 'Vagina Monologues’ This Year.” (Nov 2007), The AS Review. 